\title{
Analisis Tingkat Kepuasan Mahasiswa terhadap Kualitas Pelayanan Universitas Muhammadiyah Tasikmalaya
}

\author{
Endah Nurmahmudah ${ }^{1}$, Rissa Nuryuniarti ${ }^{2}$ \\ Universitas Muhammadiyah Tasikmalaya \\ Jl. Tamansari Km 2,5 Tasikmalaya PO BOX 115 Jawa Barat Indonesia 46196 \\ endahnurmahmudah0@gmail.com ${ }^{1}$
}

\begin{abstract}
Abstrak- Penelitian ini bertujuan untuk mengetahui tingkat kepuasan mahasiswa terhadap kualitas pelayanan di Universitas Muhammadiyah Tasikmalaya dengan mencari dimensi-dimensi pelayanan yang berpengaruh pada kepuasan mahasiswa. Metode yang digunakan adalah analisis regresi linier berganda dengan menggunakan teknik total sampling yaitu seluruh populasi dijadikan objek penelitian. Populasi dalam penelitian ini yaitu seluruh mahasiswa UMTAS semester 4. Proses pengumpulan data menerapkan TIK (teknologi informasi dan komunikasi). Dalam hal ini penyebaran dan pengisian kuesioner memanfaatkan googleform, yaitu alat pengumpul data yang sangat mudah dan efisien dari google. Peneliti hanya tinggal menginformasikan alamat shortlink yang telah dibuat yaitu bit.ly/2WZtLr7 kepada responden, dan responden dapat mengakses link tersebut dari handphone android masing-masing. Hasil penelitian menunjukan bahwa secara simultan kelima variabel berpengaruh positif dan signifikan terhadap Kepuasan mahasiswa, dengan koefisien determinasi (R2) sebesar 0,868. Artinya, kelima variabel independen mempengaruhi variabel Kepuasan mahasiswa sebesar $86,8 \%$, sedangkan selebihnya $(13,2 \%)$ dipengaruhi oleh variabel lain yang tidak diteliti dalam penelitian ini.
\end{abstract}

Kata Kunci- googleform; kepuasan; kualitas; UMTAS

\begin{abstract}
This study aims to determine the level of student satisfaction with the quality of service at Muhammadiyah University of Tasikmalaya by looking for service dimensions that affect student satisfaction. The method used is multiple linear regression analysis using total sampling technique, namely the entire population is the object of research. The population in this study were all $4^{\text {th }}$ semester UMTAS students. The process of collecting data applies ICT (information and communication technology). In this case the distribution and filling out of the questionnaire utilizes Googleform, which is a very easy and efficient data collection tool from Google. The researcher only informs the address of the shortlink that has been made, namely bit.ly/2WZtLr7 to the respondent, and the respondent can access the link from their respective Android cellphones. The results of the study show that simultaneously the five variables have a positive and significant effect on student satisfaction, with a coefficient of determination (R2) of 0.868 . That is the five independent variables effect the student satisfaction variable by $\mathbf{8 6 . 8 \%}$ while the rest $(\mathbf{1 3 . 2 \%})$ is influenced by other variables not examined in this study.
\end{abstract}

Keywords: googleform; quality; satisfaction; UMTAS

\section{PENDAHULUAN}

Budaya mutu dalam perguruan tinggi sangat penting. Perguruan tinggi dituntut harus mampu memenuhi kebutuhan mahasiswa sehingga perguruan tinggi perlu meningkatkan kualitas melalui evaluasi di dalam perguruan tinggi tersebut. Kualitas yang dimaksud menyasar ke segala bidang pelayanan mulai dari pelayanan penerimaan mahasiswa baru, bagian administrasi, akademik, kemahasiswaan, bagian keuangan, perpustakaan, laboratorium, dosen, serta saranan dan prasarana, sehingga semua civitas akademika kampus sama-sama memiliki peran dalam peningkatan kualitas pelayanan demi tercapainya kepuasan mahasiswa yang notabene merupakan konsumen utama.

Dilihat dari sudut pandang para industrialis, maka perguruan tinggi dianggap sebagai sebuah perusahaan yang memproduksi dan menjual sebuah produk yang berupa jasa pendidikan tinggi atau ilmu pengetahuan, (Kartono, 1997:26). Sehingga harus memperhatikan prinsip-prinsip manajemen perusahaan dan profesionalisme dalam mengelolanya agar bisa bertahan hidup (survive) dan berkembang.

Menurut (E.Porter, 1994:251), keberhasilan atau kegagalan sebuah perusahaan bergantung pada keunggulan bersaingnya. Konsepsi ini berlaku juga bagi perguruan tinggi terutama perguruan tinggi swasta. Oleh karena itu setiap pengelola PTS perlu selalu mengevaluasi posisi bersaing PTS-nya dan melaksanakan langkah-langkah tindakan spesifik yang perlu dilakukan untuk memperbaikinya agar unggul dalam persaingan. Sebuah PTS yang mampu mengembangkan keunggulan bersaingnya setidaktidaknya tidak akan ditinggalkan mahasiswanya dan 
minat calon mahasiswa tetap tinggi terhadap PTS tersebut.

Universitas Muhammadiyah Tasikmalaya (UMTAS) merupakan perguruan tinggi swasta yang memiliki 3 Fakultas (FIKES, FKIP, FT) dengan 13 program studi. Berdasarkan data (BAAK, 2017) jumlah mahasiswa UMTAS pada tahun 2017 tercatat sebanyak 1470 orang mahasiswa. Hal ini menunjukan bahwa Universitas Muhammadiyah Tasikmalaya (UMTAS) memiliki jumlah mahasiswa di atas angka seribu dalam usia masih sangat belia, tentunya perolehan jumlah mahasiswa ini didukung oleh banyak faktor baik marketing, manajemen, teknologi, fasilitas, dan terutama kualitas pelayanannya. Untuk mempertahankannya ini adalah tantangan bagi semua pihak civitas akademika dari mulai pimpinan, dosen sampai karyawan harus memperhatikan kepuasan mahasiswa. Sementara ini yang sudah berjalan adalah EDOM yaitu evaluasi dosen oleh mahasiswa, sedangkan evaluasi mahasiswa terhadap kualitas pelayanannya belum dapat terukur. Untuk itulah UMTAS dijadikan objek penelitian ini untuk mengukur sejauhmana tingkat kepuasan mahasiswa terhadap kualitas pelayanan yang diberikan dan melalui penelitian ini diharapkan dapat memberikan masukan kepada para pimpinan, dosen dan karyawan demi untuk kemajuan Universitas Muhammadiyah Tasikmalaya sesuai dengan visinya Menjadi Universitas yang Unggul, Islami, dan Terkemuka dalam Pengembangan Ilmu Pengetahuan, Teknologi, dan Seni (IPTEKS) pada tahun 2035.

\section{KAJIAN PUSTAKA}

Kualitas

Kualitas merupakan suatu kondisi dinamis yang berhubungan dengan produk, jasa, manusia, proses, dan lingkungan yang memenuhi atau melebihi harapan. Menurut (Kotler, 2003:84) kualitas adalah keseluruhan diri serta sifat suatu produk atau pelayanan yang berpengaruh terhadap kemampuannya untuk memuaskan kebutuhan yang dinyatakan atau tersirat.

Kualitas pelayanan adalah suatu penilaian dari seorang konsumen mengenai keseluruhan dari suatu proses penyampaian pelayanan tertentu. Penilaian ini berdasarkan pada kondisi pelayanan yang seharusnya diberikan oleh pelayanan provider (harapan dari konsumen) dengan kondisi actual dari proses penyampaian pelayanan tersebut, (Zeithamal, 1996:177).

Faktor penentu kepuasan mahasiswa hasil ekstraksi dari analisis faktor yaitu :

1. Faktor kepastian,

2. Faktor berwujud,

3. Faktor keresponsivan,

4. Faktor keandalan,

5. Faktor empati

6. Faktor fasilitas pendukung,

7. Faktor fasilitas perpustakaan.

Berdasarkan hasil penelitian (Lambone, 2012:55) faktor kepastian merupakan faktor dominan yang berpengaruh terhadap kepuasan mahasiswa.

Kepuasan Klien

Pengertian Kepuasan

Kepuasan adalah tingkat perasaan seseorang atau masyarakat setelah membandingkan hasil yang dirasakan dengan harapannya. Apabila hasil yang dirasakannya sama atau melebihi harapannya, akan timbul perasaan puas, sebaliknya akan timbul perasaan kecewa atau ketidakpuasan apabila hasil yang dirasakannya tidak sesuai dengan harapannya, (Pohan, 2007:144).

Menurut (reina, 2012:571), Faktor-faktor yang mempengaruhi kepuasan mahasiswa pada Universitas Bina Nusantara adalah :

1. Menjaga proses perkuliahan dan ujian agar terlaksana dengan baik, peningkatan kualitas dosen merupakan bentuk upaya dari universitas dalam memberikan jasa yang dijanjikan secara terpercaya dan akurat.

2. Upaya menjalin komunikasi secara efektif dan efisien dengan mahasiswa dan orang tua, mendapatkan feedback dari mahasiswa atas proses pembelajaran yang dilakukan serta mendukung pengembangan keorganisasian kemahasiswaan merupakan wujud kepekaan universitas terhadap mahasiswa.

3. Tersedianya bimbingan konseling bagi mahasiswa yang mengalami kesulitan dalam proses belajar dan kesempatan mendapatkan beasiswa merupakan bentuk penghargaan serta upaya menciptakan suasana nyaman dalam belajar merupakan empati yang ditunjukan oleh universitas kepada mahasiswa.

4. Kelengkapan prasarana kegiatan proses belajar yang dapat dilihat dengan nyata merupakan 
bentuk layanan fasilitas fisik yang diberikan oleh universitas kepada mahasiswa.

5. Untuk setiap intervensi yang dilakukan atas meningkatnya kepuasan mahasiswa sebagaimana hasil penelitian, menunjukan bahwa kelima variable kualitas pelayanan adalah signifikan.

Cara Mengukur Kepuasan

Kepuasan pasien merupakan hal yang sangat subyektif, sulit untuk diukur, dapat berubah-ubah, serta banyak sekali faktor yang berpengaruh, sebanyak dimensi di dalam kehidupan manusia. Subyektivitas tersebut bisa berkurang dan bahkan bisa menjadi obyektif bila cukup banyak orang yang sama pendapatnya terhadap sesuatu hal. Oleh karena itu, untuk mengkaji kepuasan pasien dipergunakan suatu instrumen penelitian yang cukup valid disertai dengan metode penelitian yang baik, (Suryawati, 2004: 189). Menurut Parasuraman dalam (Tjiptono, 2000:126) terdapat 10 indikator untuk mengukur kepuasan pelanggan. Dalam perkembangan selanjutnya ke sepuluh faktor tersebut dirangkum menjadi 5 (lima) dimensi mutu layanan sebagai penentu kualitas jasa, yaitu :

a. Bukti langsung (tangibles) adalah segala sesuatu yang tampak seperti : fasilitas, peralatan, kenyamanan ruangan, dan sikap petugas.

b. Keandalan (reliability) adalah elemen yang berkaitan dengan kemampuan untuk mewujudkan pelayanan yang dapat diandalkan.

c. Daya tanggap (responsiveness) adalah elemen yang berkaitan dengan kesediaan karyawan dalam membantu dan memberikan pelayan yang terbaik bagi pasien, petugas dapat memberikan informasi yang jelas, petugas memberikan pelayanan dengan segera dan tepat waktu, petugas memberikan pelayanan yang baik.

d. Jaminan (assurance) : hal ini terutama mencakup pengetahuan, kemampuan, kesopanan, dan sifat dapat dipercaya petugas. Selain itu, bebas dari bahaya saat pelayanan merupakan jaminan juga.

e. Empati (empathy) meliputi perhatian pribadi dalam memahami kebutuhan para pasien.

Menurut Kotler dalam (Chandra, 2006:130), ada beberapa cara mengukur kepuasan pelanggan yaitu dengan sistem keluhan dan saran; survei kepuasan pelanggan; pembeli bayangan; dan analisis kehilangan pelanggan.
Peraturan Undang-Undang Tentang Pelayanan Publik Menteri Pendayagunaan Aparatur Negara telah membuat pedoman tentang penyusunan Indeks Kepuasan Masyarakat melalui Kepmen Nomor: KEP/25/M.PAN/2/2004, yang dimaksudkan sebagai acuan bagi unit pelayanan instansi pemerintah dalam menyusun indeks kepuasan masyarakat, dengan tujuan untuk mengetahui tingkat kinerja unit pelayanan secara berkala sebagai bahan untuk menetapkan kebijakan dalam rangka peningkatan kualitas pelayanan publik selanjutnya. Bagi masyarakat, indeks kepuasan masyarakat dapat digunakan sebagai gambaran tentang kinerja pelayanan unit yang bersangkutan.

Universitas Muhammadiyah Tasikmalaya (UMTAS)

Sejarah Universitas Muhammadiyah Tasikmalaya

Dalam buku (UMTAS, 2017) Universitas Muhammadiyah Tasikmalaya merupakan perguruan tinggi swasta yang terlahir pada tahun 2014 melalui proses yang cukup panjang :

a. Tahun 1083 - 1999; Sekolah Perawat Kesehatan (SPK) Muhammadiyah

b. Tahun 1999 - 2002; Akademi Keperawatan (AKPER)

c. Tahun 2002 - 2006; Sekolah Tinggi Ilmu Keperawatan (STIKep)

d. Tahun 2006 - 2014; Sekolah Tinggi Ilmu Kesehatan (STIKes)

e. Tahun 2014 - sekarang; Universitas Muhammadiyah Tasikmalaya

Atas usulan Pimpinan Daerah Muhammadiyah Kota Tasikmalaya, persyarikatan Muhammadiyah dipercaya oleh pemerintah untuk menyelenggarakan perguruan tinggi dengan status Universitas berdasarkan SK Menteri P dan K Nomor 598/E/0/2014 dengan nama Universitas Muhammadiyah Tasikmalaya terdiri dari 3 Fakultas (FIKES, FKIP, FT) dan 13 Prodi (D3 Kebidanan, D3 Keperawatan, S1 Keperawatan, Profesi Keperawatan Ners, S1 BK, S1 PG-PAUD, S1 PTI, S1 Pendidikan Seni, Drama Tari dan Musik, S1 Mesin, S1 Pertambangan, S1 Lingkungan, dan S1 Elektro).

Visi Misi UMTAS

Visi UMTAS adalah : "Menjadi Universitas yang Unggul, Islami, dan Terkemuka dalam Pengembangan Ilmu Pengetahuan, Teknologi, dan Seni (IPTEKS) pada tahun 2035"

Misi UMTAS adalah : 
a. Memajukan ilmu pengetahuan, teknologi, dan seni berlandaskan nilai-nilai Al-Islam dan Kemuhammadiyahan serta tuntutan zaman dalam rangka membangun masyarakat Indonesia yang berperadaban unggul dan mencerahkan;

b. Mengembangkan sumber daya manusia berlandaskan nilai-nilai Al-Islam Kemuhammadiyahan, tuntutan zaman, serta memberi arah perubahan dalam rangka membangun masyaakat Indonesia sebagai masyarakat yang berkemajuan;

c. Mengembangkan dan memberdayakan masyarakat melalui proses pendidikan, penelitian, pengabdian kepada masyarakat, dan mengembangkan serta mengamalkan nilai-nilai Islam dan Kemuhammadiyahan sebagai sarana dakwah yang mencerahkan.

\section{Googleform}

Googleform atau yang disebut google formulir adalah alat yang berguna untuk membantu merencanakan acara, mengirim survey, memberikan siswa atau orang lain kuis, atau mengumpulkan informasi yang mudah dengan cara yang efisien. Form juga dapat dihubungkan ke spreadsheet. Jika terkait dengan bentuk, tanggapan otomatis akan dikirimkan ke spreadsheet. Jika tidak, pengguna dapat melihat mereka di "ringkasan tanggapan" dan halaman dapat diakses di menu tanggapan.

Googleform merupakan produk TIK dari google yang bisa dimanfaatkan oleh banyak kalangan tak terkecuali akademisi. Keberadaannya sangat efektif dan efisien dalam pelaksanaan penelitian terutama dalam kegiatan pengumpulan data. Peneliti hanya tinggal menginformasikan shortlink kepada responden yang dituju dan responden dengan mudah mengunduhnya dengan mengklik shortlink dari handphone android masing-masing. Pada jaman sekarang memang dibutuhkan fasilitas-fasilitas modern untuk memudahkan akses informasi. Dan googleform salah satu yang bisa kita gunakan sebagai alat untuk melakukan survey/penelitian dengan lebih efisien. Penelitian tentang pemanfaatan googleform untuk melakukan penelitian sudah banyak dilakukan seperti yang dilakukan oleh (Batubara, 2016:39) tentang Penggunaan googleform sebagai alat penilaian kinerja dosen di prodi PGMI Uniska Muhammad Arsyad Albanjari.

\section{METODE PENELITIAN}

Tujuan penelitian ini untuk mengetahui tingkat kepuasan mahasiswa terhadap kualitas pelayanan di Universitas Muhammadiyah Tasikmalaya, dan melalui penelitian ini diharapkan dapat memberikan masukan kepada para pimpinan, dosen dan karyawan demi untuk kemajuan Universitas Muhammadiyah Tasikmalaya.

Penelitian ini menggunakan analisis regresi linier berganda dengan teknik total sampling dimana jumlah sampel sama dengan populasi yaitu seluruh mahasiswa UMTAS semester 4. Proses pengumpulan data menerapkan TIK dalam hal ini penyebaran dan pengisian kuesionernya menggunakan googleform, yaitu alat pengumpul data yang sangat mudah dan efisien dari google. Peneliti hanya tinggal menginformasikan alamat shortlink yang telah dibuat yaitu bit.ly/2WZtLr 7 kepada responden, dan responden dapat mengakses link tersebut dari handphone android masing-masing.

Metode pengolahan data melalui beberapa tahap yaitu: editing (pengecekan dan penyesuaian yang diperlukan terhadap data penelitian, kuesioner telah diisi semua atau tidak); coding/pemberian kode (proses identifikasi dan klasifikasi data penelitian ke dalam skor numeric atau karakter symbol); dan scoring/pemberian skor (pemberian skor pada setiap jawaban responden diberi skor dan nilai disusun secara bertingkat berdasarkan skala likert). sangat puas (1), puas (2), tidak puas (3).

Variabel penelitian :

1. Variabel bebas X (independent):

- Variabel tangible (X1)

- Variabel reliable (X2)

- Variable responsiveness (X3)

- Variabel assurance (X4)

- Variabel emphaty (X5)

2. Variabel terikat (dependent) : Kepuasan (Y)

\section{Uji Instrumen}

a. Uji Validitas

Uji validitas merupakan suatu ukuran sah/validnya suatu instrument penelitian yaitu kuisioner. Untuk mengukur validitas menggunakan Korelasi Product Moment. Pengujian ini mengkorelasikan skor butir soal dengan skor total dengan tingkat kepercayaan $\alpha=0.05$. kuisioner dikatakan valid apabila $r$ hitung $>r$ table. Uji validitas 
menggunakan r-tabel pada taraf signifikansi 0.05 dengan nilai $\mathrm{df}=28$ (berasal dari jumlah responden 30 dikurangi 2), maka diperoleh angka 0.378.

b. Uji Reliabilitas

Pengukuran reliabilitas menggunakan Cronbach Alpha. Suatu variabel dikatakan reliabel jika memberikan nilai cronbach alpha >0.05. Uji reliabilitas instrument penelitian dari 5 dimensi kepuasan (item tangible, reliability, responsive, assurance dan empathy) masing-masing memiliki $\alpha$ sebesar $0.928,0.940,0.784,0.796$, dan 0.638 sehingga instrument penelitian ini reliable.

\section{Uji Hipotesis}

a. Uji Regresi Linier Berganda

Analisis ini digunakan untuk mengetahui seberapa besar pengaruh variabel bebas yaitu tangible $(X 1)$, Reliable (X2), Responsiveness (X3), Assurance (X4), empathy (X5) terhadap variabel terikat lainnya yaitu kepuasan. Dimana :

$$
\begin{aligned}
& \mathrm{Y}=\mathrm{a}+\mathrm{b} 1 \mathrm{x} 1+\mathrm{b} 2 \times 2+\mathrm{b} 3 \times 3+\mathrm{b} 4 \times 4+\mathrm{b} 5 \times 5+\mathrm{e} \\
& \mathrm{Y}=\text { Variabel dependen (kepuasan) } \\
& \mathrm{a}=\text { Konstanta } \\
& 1=\text { Koefisien regresi dari variable } \mathrm{x} 1 \\
& 2 \text { = Koefisien regresi dari variable } \mathrm{x} 2 \\
& 3=\text { Koefisien regresi dari variable } \mathrm{x} 3 \\
& 4=\text { Koefisien regresi dari variable } \mathrm{x} 4 \\
& 5=\text { Koefisien regresi dari variable } \mathrm{x} 5 \\
& 1 \quad=\text { Tangible } \\
& 2 \quad=\text { Reliable } \\
& 3 \quad=\text { Respossiveness } \\
& 4 \quad=\text { Assurance } \\
& 5=\text { Emphaty } \\
& \mathrm{e} \quad=\text { Error }
\end{aligned}
$$

b. Uji T

Uji ini digunakan untuk membuktikan hipotesis yang diajukan, apakah variable independent berpengaruh terhadap kepuasan mahasiswa. Uji $\mathrm{t}$ ditentukan berdasarkan ketentuan sebagai berikut:

1) Apabila angka probabilitas signifikansi $>0.05$ maka Ha ditolak

2) Apabila angka probabilitas signifikansi $<0.05$ maka Ha diterima

\section{c. Uji F}

Uji $F$ merupakan cara menganalisis untuk mengetahui apakah terdapat pengaruh yang signifikan atau tidak antara semua variable independen terhadap kepuasan mahasiswa pada pelayanan di Universitas Muhammadiyah Tasikmalaya.

\section{HASIL DAN PEMBAHASAN}

A. Hasil Penelitian

Hasil penelitian ini dapat diketahui bahwa penilaian mahasiswa terhadap kualitas pelayanan yang diberikan Universitas Muhammadiyah Tasikmalaya yang terdiri dari indikator tangible, reliability, responsive, assurance dan empathy mencakup berbagai jenis pelayanan yang diberikan seperti pelayanan PMB (Penerimaan Mahasiswa Baru), Pelayanan BAAK, pelayanan keuangan, Perpustakaan, Laboratorium, Dosen, Sarana dan prsarana memiliki peran yang penting dalam kepuasan mahasiswa. Seperti terlihat pada table. 1 berikut:

\section{Table 1 Kepuasan Mahasiswa terhadap kualitas pelayanan} di Universitas Muhammadiyah Tasikmalaya

\begin{tabular}{llrrrr}
\hline No & Variabel & \multicolumn{2}{c}{ Puas } & \multicolumn{2}{c}{ Tidak Puas } \\
\cline { 3 - 6 } & & $\mathbf{f}$ & $\mathbf{\%}$ & $\mathbf{f}$ & \% \\
\hline 1 & Tangible & 187 & 48.3 & 200 & 51.7 \\
2 & Reliability & 192 & 49.6 & 195 & 50.4 \\
3 & Responsive & 224 & 57.9 & 163 & 42.1 \\
4 & Asurance & 204 & 52.7 & 183 & 47.3 \\
5 & Empathy & 262 & 67.7 & 125 & 32.3 \\
\hline
\end{tabular}

Tabel 1 menjelaskan bahwa variabel yang memiliki nilai ketidakpuasan paling tinggi adalah tangible $(51.7 \%)$ dan reliability $(50.4 \%)$. Sedangkan variabel yang memiliki tingkat kepuasan yang tinggi adalah empathy $(67.7 \%)$ responsive $(57.9 \%)$ dan assurance $(52.7 \%)$.

Hasil uji regresi penelitian dapat dilihat pada table 2 berikut:

Tabel.2 Hasil Uji Regresi Linier Berganda Kepuasan Mahasiswa

\begin{tabular}{lccc}
\hline \multicolumn{1}{c}{ Variabel } & $\begin{array}{c}\text { Unstandardi } \\
\text { zed } \\
\text { Coefficients }\end{array}$ & t- hitung & Sign t \\
\hline Kepuasan & 0.059 & 3.412 & \\
Tangible $\left(\mathrm{X}_{1}\right)$ & 0.509 & 17.047 & 0.000 \\
Reliability $\left(\mathrm{X}_{2}\right)$ & 0.161 & 5.801 & 0.000 \\
Responsive $\left(\mathrm{X}_{3}\right)$ & 0.166 & 5.197 & 0.000 \\
Assurance $\left(\mathrm{X}_{4}\right)$ & 0.180 & 6.723 & 0.000 \\
Empathy $\left(\mathrm{X}_{5}\right)$ & 0.071 & 2.988 & 0.003 \\
\hline Uji F : 499.575 & & & \\
Sign F : 0.000 & & & \\
R Square $: 0.868$ & & & \\
\hline
\end{tabular}


Berdasarkan tabel.2 maka dapat disusun persamaan regresi linier berganda :

$$
Y=0.059+0.509 X_{1}+0.161 X_{2}+0.166 X_{3}+0.180
$$

$\mathrm{X}_{4}+0.071 \mathrm{X}_{5}+\mathrm{e}$

Persamaan diatas dapat dijelaskan sebagai berikut:

a. Konstanta sebesar 0.059 artinya bahwa tingkat kepuasan mahasiswa terhadap pelayanan di UMTAS dapat dinaikan sebesar 0.059 meskipun nilai-nilai variabel independent tidak mengalami penambahan ataupun pengurangan.

b. Nilai koefisien regresi variable tangible $\left(\mathrm{X}_{1}\right)$ sebesar 0.509 , artinya setiap kenaikan variable tangible satu satuan maka kepuasan mahasiswa akan mengalami kenaikan sebasar 0.509.

c. Nilai koefisien regresi variable reliability $\left(\mathrm{X}_{2}\right)$ sebesar 0.161 , artinya setiap kenaikan variable reliability satu satuan maka kepuasan mahasiswa akan mengalami kenaikan sebasar 0.161.

d. Nilai koefisien regresi variable responsive $\left(\mathrm{X}_{3}\right)$ sebesar 0.166 , artinya setiap kenaikan variable responsive satu satuan maka kepuasan mahasiswa akan mengalami kenaikan sebasar 0.166.

e. Nilai koefisien regresi variable assurance $\left(\mathrm{X}_{4}\right)$ sebesar 0.180 , artinya setiap kenaikan variable empathy satu satuan maka kepuasan mahasiswa akan mengalami kenaikan sebasar 0.180.

f. Nilai koefisien regresi variable empathy $\left(\mathrm{X}_{5}\right)$ sebesar 0.071 , artinya setiap kenaikan variable empathy satu satuan maka kepuasan mahasiswa akan mengalami kenaikan sebasar 0.071.

Pengujian Secara Parsial (Uji t)

a. $\mathrm{t}$ hitung $\mathrm{X}_{1} 17.047>\mathrm{t}$ table 1.649. dengan signifikansi $0.000<0.05$ maka variabel ini berpengaruh terhadap variabel $\mathrm{Y}$

b. $\mathrm{t}$ hitung $\mathrm{X}_{2} 5.801>\mathrm{t}$ table 1.649. dengan signifikansi $0.000<0.05$ maka variabel ini berpengaruh terhadap variabel $\mathrm{Y}$

c. t hitung $X_{3} 5.197>t$ table 1.649. dengan signifikansi $0.000<0.05$ maka variabel ini berpengaruh terhadap variabel $\mathrm{Y}$

d. $\mathrm{t}$ hitung $\mathrm{X}_{4} 6.723>\mathrm{t}$ table 1.649. dengan signifikansi $0.000<0.05$ maka variabel ini berpengaruh terhadap variabel $\mathrm{Y}$

e. $\mathrm{t}$ hitung $\mathrm{X}_{4} 2.988>\mathrm{t}$ table 1.649. dengan signifikansi $0.003<0.05$ maka variabel ini berpengaruh terhadap variabel $\mathrm{Y}$
Dari paparan diatas semua variabel memiliki pengaruh secara parsial terhadap kepuasan mahasiswa, yaitu tangible $\left(X_{1}\right)$, reliability $\left(X_{2}\right)$, responsive $\left(X_{3}\right)$, assurance $\left(\mathrm{X}_{4}\right)$, empathy $\left(\mathrm{X}_{5}\right)$. Untuk mengetahui variabel yang paling dominan pengaruhnya dari ke lima indikator adalah dengan melihat besar kecilnya nilai t hitung. Dari table diketahui bahwa nilai tertinggi t hitung yaitu tangible $\left(\mathrm{X}_{1}\right)$, kedua assurance $\left(\mathrm{X}_{4}\right)$, ketiga reliability $\left(\mathrm{X}_{2}\right)$, keempat responsive $\left(\mathrm{X}_{3}\right)$, dan terakhir empathy $\left(\mathrm{X}_{5}\right)$.

Pengujian Secara Simultan (Uji F)

Berdasarkan hasil uji secara simultan menunjukkan bahwa nilai $\mathrm{F}$ hitung adalah sebesar 499.575 dengan nilai probabilitas $0.000<\alpha=0.05$. artinya variabel tangible, reliability, responsive, assurance dan empathy secara simultan mempunyai pengaruh yang signifikan terhadap kepuasan mahasiswa (Y) pada pelayanan di UMTAS.

Pengujian Koefisien Determinasi

Berdasarkan hasil pengujian koefisien determinasi menunjukkan bahwa nila R2 sebesar 0.868. Artinya sebesar $86.8 \%$ tingkat kepuasan mahasiswa dapat dijelaskan oleh variabel tangible, reliability, responsive, assurance dan empathy, sedangkan sisanya sebesar $13.2 \%$ (100\%-86.8\%) dipengaruhi oleh variabel lain.

Pembahasan

Kepuasan mahasiswa terhadap layanan di Universitas Muhammadiyah Tasikmalaya dapat dibuktikan dengan hasil nilai $\mathrm{F}$ hitung sebesar sebesar 499.575 dengan nilai probabilitas $0.000<\alpha=0.05$ sehingga H0 ditolak dan $\mathrm{Ha}$ diterima. Hal ini menunjukkan bahwa ke lima indikator kepuasan memiliki pengaruh yang simultan terhadap kualitas pelayanan di UMTAS.

Dimensi-dimensi kepuasan masing-masing memiliki pengaruh yang sama terlihat dari hasil uji t yang menunjukkan bahwa nilai tarap signifikansi setiap dimensi memiliki nilai yang sama yaitu sebesar $0.000<\alpha=0.05$. Sehingga kedudukan setiap dimensi mempunyai pengaruh yang sama, tidak ada dimensi yang dominan ataupun kurang. Artinya semua dimensi memiliki pengaruh yang signifikan terhadap kepuasan mahasiswa.

Dilihat dari nilai t hitung dibandingkan dengan nilai t table 5 indikator kepuasan memiliki tingkatan kepuasan dari yang tertinggi sampai dengan terendah. Variabel tangible memiliki nilai ketidakpuasan yang paling tinggi diantara variabel yang lain, namun variabel ini juga yang memiliki pengaruh paling besar 
terhadap kualitas pelayanan di Universitas Muhammadiyah Tasikmalaya. Sedangkan empathy yang memiliki kepuasan paling tinggi ternyata hasil analisis regresi berganda menunjukkan bahwa variabel ini memiliki nilai $\mathrm{t}$ hitung paling rendah artinya variabel ini berpengaruh cukup kecil dibandingkan dengan variabel yang lainnya.

Koefisien determinasi dalam penelitian ini menunjukkan nilai yang cukup tinggi mendekati angka 1 , artinya variabel independent sangat berpengaruh terhadap variabel dependent dengan hasil 0.868 . Kepuasan dan ketidakpuasan mahasiswa terhadap pelayanan dapat diuraikan sebagai berikut:

Variabel tangible (bukti fisik) yang terdiri dari 15 pertanyaan tentang bagaimana keadaan fasilitas di setiap unit pelayanan apakah sudah sesuai standar atau tidak. Ketidakpuasan mahasiswa terhadap pelayanan yang paling tinggi yaitu tidak puas terhadap fasilitas olah raga yang tidak lengkap, fasilitas parkir, ruang belajar yang kurang memadai, jaringan internet yang masih belum terkoneksi dengan baik. Sedangkan bukti fisik lainnya mahasiswa merasa puas.

Realiability (keandalan) yang terdiri dari 16 pertanyaan tentang elemen yang berkaitan dengan kemampuan untuk mewujudkan pelayanan yang dapat diandalkan. Ketidakpuasan mahasiswa terhadap pelayanan paling tinggi yaitu tidak puas terhadap pengaturan system pembagian ruangan kelas dan koleksi buku yang tidak lengkap untuk semua prodi. Sedangkan pelayanann lainnya sudah dapat diandalkan.

Assurance (jaminan) yang terdiri dari 7 pertanyaan tentang kemampuan dan sifat yang dapat dipercaya dari petugas. Variabel ini meiliki nilai ketidakpuasan yang cukup kecil hal ini hanya tergambar pada kurang puasnya mahasiswa terhadap dosen yang tidak tepat waktu bila ada janji dengan mahasiswa serta ketidakpuasan terhadap pelayanan keuangan dimana biaya yang dibayarkan tidak sesuai dengan hasil rekapitulasi keuangan. Sedangkan kemampuan dan sifat petugas dalam memberikan pelayanan sudah puas.

Responsive (daya tanggap) yang terdiri dari 6 pertanyaan tentang elemen yang berkaitan dengan kesediaan karyawan dalam membantu dan memberikan pelayanan yang terbaik. Ketidakpuasan mahasiswa terhadap pelayanan yaitu pegawai BAAK tidak cepat tanggap dalam menyelesaikan keluhan dari mahasiswa. Untuk pelayanan yang lainnya mahasiswa sudah puas.

Empathy terdiri dari 4 pertanyaan tentang perhatian pribadi dalam memahami kebutuhan mahasiswa. Ketidakpuasan mahasiswa terhadap pelayanan pegawai BAAK yang tidak mendengarkan dengan baik dan tidak menyelesaikan setiap keluhan dari mahasiswa. Adapun kepuasan mahasiswa terutama dari pelayanan dosen kepada mahasiswa.

\section{KESIMPULAN DAN SARAN}

Kesimpulan

Analisis tingkat kepuasan mahasiswa dari 5 variabel memiliki pengaruh secara simultan dan parsial. pengaruh secara parsial yang paling berpengaruh berdasarkan $\mathrm{t}$ hitung berpengaruh adalah variabel tangible akan tetapi semua indicator berdasarkan taraf signifikan memiliki pengaruh yang sama terhadap kepuasan mahasiswa. Ke lima variabel independent memiliki pengaruh sebesar $86.6 \%$ terhadap variabel kepuasan.

Saran

Berdasarkan hasil penelitian ini maka pihak Universitas sebaiknya segera melakukan perbaikan untuk meningkatkan kualitas pelayanannya terutama pada 2 dimensi yaitu:

1. Sarana dan Prasarana

Perbaikan infrastruktur seperti ruang kelas, fasilitas olah raga, parkir dan jaringan internet, penambahan buku referensi, serta pembagian ruangan kelas.

2. Karyawan

Jobdesk yang jelas, adanya reward dan punishment yang tegas serta peningkatan loyalitas karyawan.

\section{REFERENSI}

[1] BAAK 2017 Tasimalaya Universitas Muhammadiyah Tasikmalaya

[2] Batubara, H. H. (2016:39, Juni). Penggunaan Google Form Sebagai Penilaian Kinerja Dosen Di Proi PGMI Uniska Muhammad Arsyad Al Banjari. Jurnal Pendidikan Dasar Islam : Al Bidayah, 8 No. 1, 39-50. Retrieved from http://digilib.uin-suka.ac.id/25309/4/

[3] E.Porter, M. (1994:251). Keunggulan Bersaing Menciptakan dan Mempertahankan Kinerja Unggul. (T. P. Aksara, Trans.) Jakarta: Binarupa Aksara. 
[4] I.S, P. (2002). Jaminan Mutu Layanan Kesehatan, Dasar-dasar Pengertian dan Penerapan. Jakarta: Buku Kedokteran.

[5] Kartono, K. (1997:26). Tinjauan Politik Mengenai Sistem Pendidikan Nasional Beberapa Kritik an Sugesti (Cetakan Pertama ed.). Jakarta: PT Pradnya Paramita.

[6] Kotler, P. (2003:84). Marketing Management (11th Edition ed.). New Jersey: Prentice Hall Int'l.

[7] Lambone, I. P. (2012:55). Tingkat Kepuasan mahasiswa Terhadap Kualitas Pelayanan Universitas Sam Ratulangi Menggunakan Analisis Faktor. Jurnal MIPA UNSRAT, 1 (1), 52-56. Retrieved from https://ejournal.unsrat.ac.id/index.php/jmuo/a rticle/view/431

[8] Chandra Manajemen Pelayanan Jasa 2006:130 Yogyakarta Andi Offset

[9] reina, r. (2012:571). Faktor-faktor yang Mempengaruhi Kepuasan Mahasiswa Pada Universitas Bina Nusantara. Jurnal BINUS
BUSINESS REVIEW, 563-572. doi:https://doi.org/10.21512/bbr.v3i1.1343

[10] Suryawati, C. (2004: 189). Kepuasan Pasien Rumah Sakit. Jurnal Manajemen Pelayanan Kesehatan (Tinjauan Teoritis dan Penerapannya pada penelitian), 07 No 04, 189-194. Retrieved from https://journal.ugm.ac.id/jmpk/article/view/29 $13 / 2633$

[11] Tjiptono, F. (2000:126). Strategi Pemasaran. Yogyakarta: Andi Offset.

[12] UMTAS. (2017). Rencana Induk Perencanaan. Tasikmalaya: Universitas Muhammadiyah Tasikmalaya.

[13] Zeithamal, V. A. (1996:177). Delivering Quality Service : Balancing Customer Perciptions and Expectations. New York: The Free Press. 